\title{
Optimizing storage temperature of liquid bovine semen diluted in INRA96
}

\author{
Edel M. Murphy, ${ }^{*} \dagger$ Ciara O’ Meara, $†$ Bernard Eivers, $†$ Patrick Lonergan, $\ddagger$ and Sean Fair*1 \\ *Laboratory of Animal Reproduction, Department of Biological Sciences, School of Natural Sciences, Faculty of Science and Engineering, \\ University of Limerick, Limerick, V94 T9PX, Ireland \\ †National Cattle Breeding Centre, Naas, Co. Kildare, W91 WF59, Ireland \\ $\ddagger$ School of Agriculture and Food Science, University College Dublin, Belfield, Dublin 4, D04 N2E5, Ireland
}

\begin{abstract}
Temperature regulation of liquid bovine semen can be difficult in field situations. Two experiments were carried out to assess the effect of storage temperature on in vitro sperm characteristics and 60-d nonreturn rate (NRR) following artificial insemination (AI) of liquid bovine semen. In experiment 1 , the effect of storage of liquid bovine semen in INRA96 diluent (IMV Technologies, L'Aigle, France) at 1 of 5 storage temperatures (5, 15 , or $28^{\circ} \mathrm{C}$, and fluctuating between 5 and $15^{\circ} \mathrm{C}$ or 5 and $28^{\circ} \mathrm{C}$ ) on total and progressive motility and kinematic parameters was assessed objectively via computer-assisted sperm analyzer on d 0, 1, 2, 3, and 4 after collection. Fluctuating temperatures were designed to mimic day- to nighttime variation. In experiment 2 , we assessed the field fertility of liquid semen stored at a constant 5 or $15^{\circ} \mathrm{C}$ or in an unregulated manner and compared with that of frozen-thawed semen (total of $\mathrm{n}=106,738$ inseminations). In experiment 1 , we detected a linear decrease in motility with increased duration of storage. Semen stored at a constant $15^{\circ} \mathrm{C}$ or fluctuating between 5 and $15^{\circ} \mathrm{C}$ had greater total motility than semen held at 5 or $28^{\circ} \mathrm{C}$ or fluctuating between 5 and $28^{\circ} \mathrm{C}$; however, semen stored at $15^{\circ} \mathrm{C}$ and fluctuating between 5 and $15^{\circ} \mathrm{C}$ did not differ from each other. Semen held at a constant 5 or $15^{\circ} \mathrm{C}$ or fluctuating between 5 and $15^{\circ} \mathrm{C}$, although not differing from each other, had higher progressive motility scores than that held at $28^{\circ} \mathrm{C}$ or fluctuating between 5 and $28^{\circ} \mathrm{C}$. Semen stored at a constant $28^{\circ} \mathrm{C}$ exhibited poor motility and velocity values but had high progressive motion values compared with that all other storage temperatures; however, the other storage temperatures did not differ from each other in relation to motility kinematics. In experiment 2 , semen stored at a constant $5^{\circ} \mathrm{C}$ resulted in a lower 60 -d NRR (62.5\%) than storage at constant
\end{abstract}

Received November 27, 2017.

Accepted February 6, 2018.

${ }^{1}$ Corresponding author: sean.fair@ul.ie $15^{\circ} \mathrm{C}$ or unregulated temperature or frozen-thawed semen $(73.6,74.6$, and $74.4 \%$, respectively. In conclusion, sperm stored in IRNA96 are quite tolerant in terms of storage temperature, retaining acceptable motility between 5 and $15^{\circ} \mathrm{C}$. Storing semen at a constant $15^{\circ} \mathrm{C}$ resulted in greater in vitro sperm motility and higher NRR rates than storage at $5^{\circ} \mathrm{C}$ and did not differ in NRR from frozen-thawed semen or semen stored at an unregulated temperature; however, lower storage temperatures were shown to be more detrimental to sperm in vivo than unregulated storage conditions.

Key words: storage temperature, liquid semen, bovine, artificial insemination, nonreturn rate

\section{INTRODUCTION}

Liquid semen has traditionally been confined to countries such as Ireland and New Zealand with seasonal grass-based systems where inseminations are confined to a short breeding season (Verberckmoes et al., 2005). Liquid semen is principally used for only 2.5 to $3 \mathrm{~d}$ after collection because a reduction in fertility has been reported thereafter (Vishwanath and Shannon, 2000). Liquid semen has a distinct advantage over frozenthawed semen as the reduced sperm concentration per straw (approximately 3-5 million vs. $15-20$ million sperm, respectively; Murphy et al., 2013) allows for approximately 3 times more semen straws to be produced. Hence, the use of liquid semen maximizes the number of insemination straws produced per ejaculate compared with frozen-thawed semen. Currently, liquid bovine semen straws in Ireland are stored in an unregulated temperature flask, which is subjected to natural day/ night temperature fluctuations, with an average spring temperature of $15^{\circ} \mathrm{C}$ recorded within the flask, whereas minimum and maximum temperatures recorded in one study were 6.4 and $27.9^{\circ} \mathrm{C}$, respectively (Murphy et al., 2015). The optimum storage temperature of semen can depend on the species involved and the semen dilution technology implemented, with studies suggesting that a temperature between 18 and $24^{\circ} \mathrm{C}$ is optimal for bovine semen when semen is purged with nitrogen gas 
$\left(\mathrm{N}_{2}\right.$; Vishwanath and Shannon, 2000); storage at $5^{\circ} \mathrm{C}$ has also been recommended for bovine (Black, 2006), equine (Ball et al., 2001), and ovine (O'Hara et al., 2010; Gil et al., 2011) semen.

An accepted principle of semen dilution technology is that survival of sperm over prolonged periods is inversely related to their metabolic activity (Salisbury and Vandemark, 1961). Various strategies to reduce metabolism have been assessed to enhance sperm survival such as reducing storage temperature, lowering $\mathrm{pH}$ (Foote, 1964), and $\mathrm{N}_{2}$ gassing (Shannon, 1965). Although storage of liquid semen at $5^{\circ} \mathrm{C}$ may reduce the metabolic activity of sperm, therefore extending their fertile lifespan (Shannon et al., 1984), one disadvantage is an increase in intracellular sodium concentration to cytotoxic levels due to a reduction in the activity of the sodium-potassium pump that diffuses ions across the cell membrane (Vishwanath and Shannon, 2000). Storing semen at reduced temperatures may also result in an increased incidence of cold shock injuries, which are associated with morphological membrane changes consistent with a lipid phase transition (Drobnis et al., 1993). Although the mechanisms underlying cold shock are not fully understood, sperm membrane integrity is thought to decline due to a loss of membrane phospholipids at reduced temperatures, resulting in reduced semen quality (Batellier et al., 2001). To avoid the damage sustained by reduced temperatures, protocols to inhibit pathways detrimental to the survival of sperm at ambient temperatures $\left(15-20^{\circ} \mathrm{C}\right)$ were devised (Shannon and Curson, 1984). Although storing semen at 15 to $20^{\circ} \mathrm{C}$ may prevent the occurrence of cold shock injuries and thus improve fertility, it has been postulated that the production of reactive oxygen species, as a by-product of metabolism, is accelerated at higher storage temperatures (Vishwanath et al., 1996; Pino et al., 2013).

Murphy et al. (2015) reported that semen stored at $15^{\circ} \mathrm{C}$ in an egg-yolk based diluent (Caprogen) had greater total and progressive motility than semen stored at $5,22,32^{\circ} \mathrm{C}$, or fluctuating (day/night) between these temperatures. That study also reported that sperm were tolerant to temperatures between 5 and $22^{\circ} \mathrm{C}$. Milk-based extenders, such as INRA96 (IMV Technologies, L'Aigle, France), are widely used in the dilution and storage of equine semen cooled to between 4 and $8^{\circ} \mathrm{C}$ (Batellier et al., 2001). However, Batellier et al. (1997) demonstrated that the survival of equine sperm stored in INRA96 at $15^{\circ} \mathrm{C}$ was greater than that stored in milk-based extenders at $4^{\circ} \mathrm{C}$, and others have demonstrated improved pregnancy rates when equine semen was stored at $15^{\circ} \mathrm{C}$ (Batellier et al., 2001; Cuervo-Arango et al., 2014). Although liquid bull semen has traditionally been stored at ambient temperature in the egg-yolk based diluent Caprogen, we have recently demonstrated that INRA96 is effective for the preservation of bovine semen stored at ambient temperature, resulting in similar calving rates to semen diluted in Caprogen (Murphy et al., 2017). Furthermore, as the preparation of Caprogen is complex and time consuming, the use of INRA96 is a suitable alternative for the dilution and storage of bovine semen and is more convenient for the busy working schedule of an AI center as it can be used directly off the shelf, thus reducing time constraints within the laboratory. Therefore, the objectives of this study were to investigate whether temperature regulation could improve in vitro sperm motility and kinematic parameters and in vivo fertility of liquid bovine semen stored in INRA96.

\section{MATERIALS AND METHODS}

\section{Experiment 1: Effect of Constant or Fluctuating Storage Temperatures on Sperm Motility and Kinematic Parameters}

The aim of this experiment was to establish the optimal storage temperature range for liquid bovine semen stored in INRA96 (IMV Technologies). We assessed the effect of 5 storage temperature conditions (constant 5,15 , or $28^{\circ} \mathrm{C}$, fluctuating between 5 and $15^{\circ} \mathrm{C}$, or fluctuating between 5 and $28^{\circ} \mathrm{C}$ ) on total and progressive motility and kinematic parameters of liquid bovine semen for up to $4 \mathrm{~d}$ post-collection. Semen was collected from Holstein Friesian bulls $(\mathrm{n}=7)$ at a commercial AI center on 3 different occasions (occasion = replicate). The raw ejaculate was partially diluted in $10 \mathrm{~mL}$ of warmed INRA96 at $37^{\circ} \mathrm{C}$ and transported in a temperature-regulated cooler box at $18^{\circ} \mathrm{C}$ to the laboratory (up to $3 \mathrm{~h}$ of transport). On arrival, the ejaculate was assessed for sperm concentration using a Coulter counter (Z Series, Beckman Coulter, Clare, Ireland) and scored for total motility (\%) and gross motility on a subjective 5-point scale ( $1=$ twitching/ no forward progressive motility; $5=$ excellent forward progressive motility) to ensure all samples were of a commercial standard (results not shown). Microscopic assessments were conducted by the same technician, and the initial quality control cut-off values were total and gross motility of $\geq 70 \%$ and a score of $\geq 3$, respectively. Any ejaculates failing to meet these criteria are routinely rejected and would not be included in the study; however, no ejaculates were rejected upon initial quality control checks.

Ejaculates were fully diluted in INRA96 to achieve a concentration of $5 \times 10^{6}$ sperm per 0.25 -mL insemi- 
nation dose. Semen from each bull was kept separate and ejaculates were split such that each bull was represented equally in each treatment. Straws were filled according to routine procedures and stored at 1 of 5 storage temperatures: 5,15 , or $28^{\circ} \mathrm{C}$, fluctuating between 5 and $15^{\circ} \mathrm{C}\left(\mathbf{5} \sim \mathbf{1 5}^{\circ} \mathbf{C}\right)$, or fluctuating between 5 and $28^{\circ} \mathrm{C}\left(\mathbf{5} \sim \mathbf{2 8 ^ { \circ }} \mathbf{C}\right)$. Fluctuating temperatures were designed to mimic day to night fluctuations; semen was held at $5^{\circ} \mathrm{C}$ at night (in a fridge) and at either $15^{\circ} \mathrm{C}$ (in temperature-regulated box) or $28^{\circ} \mathrm{C}$ (in an incubator) during the day. To allow a gradual temperature fluctuation, straws were placed in an insulated plastic container and stored at their respective temperatures for a minimum of $12 \mathrm{~h}$ daily. Temperatures fluctuated between 28 and $5^{\circ} \mathrm{C}$ and vice versa over at least 3.5 h. Samples ( $\mathrm{n}=4$ straws) from each treatment were assessed in a randomized sequence to remove bias due to sampling order.

\section{Computer-Assisted Sperm Analysis}

Total and progressive motility and kinematic parameters were objectively assessed on d $0,1,2,3$, and 4 after semen collection ( $\mathrm{d} 0=3 \mathrm{~h}$ after collection) using the IVOS-II Computer Assisted Sperm Analyzer (CASA; IMV Technologies) system driven by software version 14 (Hamilton Thorne Inc., Beverly, MA). Straws (n = 4 per ejaculate) were warmed to $35^{\circ} \mathrm{C}$ for $30 \mathrm{~s}$, dried fully to remove any excess water, cut at the sealed end, and placed separately into a warmed Eppendorf tube $\left(35^{\circ} \mathrm{C}\right)$. The plug end of each straw was then cut to expel the contents of the straw into the Eppendorf tube and the semen sample was mixed thoroughly to ensure homogeneity. The samples were incubated for approximately $10 \mathrm{~min}$, and 1 drop $(3 \mu \mathrm{L})$ of diluted semen was placed in a prewarmed chamber $\left(37^{\circ} \mathrm{C}\right.$; Leja counting chamber, depth $20 \mu \mathrm{m}$; Microptics, Barcelona, Spain) and analyzed for sperm motility and kinematic parameters. A minimum of 1,000 sperm were analyzed in at least 8 microscopic fields with 30 frames acquired per field at a frame rate of $60 \mathrm{~Hz}$. Objects incorrectly identified as sperm were edited out using the playback function. The CASA-derived motility and kinematic characteristics (Mortimer, 2000) assessed were total motility (\%), progressive motility (\%), proximal and distal droplets (\%), as well as average path velocity (VAP $>10 \mu \mathrm{m} / \mathrm{s}$ ), straight line velocity, curvilinear velocity (VCL), linearity, straightness, amplitude of lateral head displacement (ALH), and beat cross frequency. Regarding analysis settings, the CASA was set to standard factory settings for bull semen; sperm with straightness of $>80 \%$ and VAP $>50 \mu \mathrm{m} / \mathrm{s}$ were considered progressively motile.

\section{Experiment 2: Effect of Storage Temperature on Field Fertility of Liquid Semen}

The aim of this experiment was to assess the effect of 3 storage temperatures on 60 -d nonreturn rate (NRR) following AI; 2 temperatures were selected based on the outcome of experiment $1\left(5\right.$ and $\left.15^{\circ} \mathrm{C}\right)$ and the third was the industry standard, which involves storage of straws in an unregulated temperature flask. Semen was collected from Holstein Friesian bulls $(\mathrm{n}=16$; denoted A to $\mathrm{P}$ ) at a commercial AI center from mid-April to early June 2017. There were 20 collection days in total, with 3 bulls used per collection day (60 ejaculates; $\sim 3-4$ ejaculates per bull). Following assessment for volume, concentration, and motility (as described in experiment 1 ), each acceptable ejaculate was diluted to $5 \times 10^{6}$ sperm per $0.25-\mathrm{mL}$ insemination dose in INRA96 and processed and filled as per routine procedure. Each batch of liquid semen was clearly labeled and distributed for insemination on the day of collection. Liquid semen was transported to the distribution center at a constant $15^{\circ} \mathrm{C}$ and distributed to technicians, where it was then stored at either a constant $5^{\circ} \mathrm{C}$ or $15^{\circ} \mathrm{C}$ or in an unregulated flask; mean low and high daily atmospheric temperature values recorded during the trial period were 6.8 and $15.9^{\circ} \mathrm{C}$, with minimum and maximum temperatures of 0.3 and $21.6^{\circ} \mathrm{C}$, respectively (Met Éireann, 2017). Liquid semen was used for up to $2 \mathrm{~d}$ after collection on heifers $(\mathrm{n}=3,644)$ and multiparous $(n=44,561)$ dairy cows. Due to quarantine restrictions, which require that frozen semen is held for 30 d before use (Irish Statue Book, 2004), frozen-thawed semen doses $\left(15 \times 10^{6}\right.$ sperm per dose $)$ were derived from previously collected ejaculates from the same 16 bulls, which were processed and frozen using routine procedures ( $\mathrm{n}=58,533$ inseminations consisting of 10,440 heifers and 48,093 multiparous dairy cows) as described by Murphy et al. (2017).

\section{Field Inseminations}

Inseminations were carried out in mid-April to early June 2017 (coinciding with the peak dairy breeding season) in Irish dairy herds $(\mathrm{n}=449)$. The majority $(95.7 \%)$ of inseminations were in Holstein Friesian cows $(\mathrm{n}=102,158)$ but small numbers of cows of other breeds were represented: Jersey $(\mathrm{n}=3,129)$, Montbéliarde $(\mathrm{n}=246)$, Norwegian Red $(\mathrm{n}=969)$, Swedish Red cows $(\mathrm{n}=42)$, and other $(\mathrm{n}=194$; includes Ayrshire, Rotbunte, Meuse Rhine Issel, and Brown Swiss). Technicians $(\mathrm{n}=243)$ were grouped by geographical area and each technician was assigned a storage temperature for the duration of the trial: $5^{\circ} \mathrm{C}, 15^{\circ} \mathrm{C}$, or 
unregulated. For each insemination, the AI technician recorded the bull code, cow tag number, and the straw code on an electronic handheld device. Insemination and NRR data were captured using the Irish Cattle Breeding Federation (ICBF, Bandon, Co. Cork) database by cross-referencing the technician name with the bull code and semen type used on each date within the trial period. Obvious errors were extracted from the data set and data were then interrogated to remove animals $(\mathrm{n}=10,917)$ based on the following criteria: cows that were not at first AI, cows that received 2 inseminations from 2 different bulls or treatments, or cows that were not of a dairy breed. However, if a cow received 2 inseminations from the same bull with the same treatment within $5 \mathrm{~d}$ of each other, the record was kept and the second date was assumed correct. After editing, 106,738 inseminations remained for experiment 2.

Cow characteristics such as parity, DIM, and fertility sub-index were included in the model. Fertility subindex is a key component of the Economic Breeding Index (EBI) comprising $\sim 35 \%$ of the total EBI (ICBF, 2017). The EBI is an estimate of the economic value of an animal's genetic merit. It was established to combat a decline in reproductive performance by providing farmers with a profit index enabling the selection of elite sires to breed replacement heifers with increased milk yield and reproductive performance and improved health traits (Berry et al., 2005).

\section{Statistical Analysis}

Data from experiment 1 were examined for homogeneity of variance and analyzed using the general linear model (GLM) repeated-measures procedure with a compound symmetry covariance structure in SPSS software (version 22.0; IBM Corp., Chicago, IL). In experiment 2, the NRR data were compared using Pearson's chi-squared procedure in SPSS. The dependent variable in the analysis was NRR $(1=$ pregnant, 0 = not pregnant). In addition, a GLM for binomial data was used to assess several fixed effects on NRR, including temperature, bull, parity, breed, fertility subindex, DIM, herd, and technician. Each fixed effect was assessed for an interaction with temperature treatment. All post hoc tests were carried out using the Bonferroni test. Results are reported as the mean \pm standard error of the mean (SEM) in experiment 1 and as the estimated marginal means in experiment 2 , to adjust for imbalance between numbers of inseminations in each treatment. Values were considered to differ significantly at $P<0.05$.

\section{RESULTS}

\section{Experiment 1: Effect of Constant or Fluctuating Storage Temperatures on Sperm Motility and Kinematic Parameters}

We detected an effect of storage temperature and day on both total and progressive motility of liquid semen (Figure 1; $P<0.01$ ); however, there was no temperature $\times$ day interaction $(P>0.05)$. From $d 0$ to 4 across all treatments, the percentage of total and progressively motile sperm declined linearly. Semen held at a constant $15^{\circ} \mathrm{C}$ had a higher total motility score throughout storage compared with semen held at 5,28 , or $5 \sim 28^{\circ} \mathrm{C}(P<0.05)$; however, this did not differ from that of semen held at $5 \sim 15^{\circ} \mathrm{C}(P>0.05)$. Semen held at 5,15 , and $5 \sim 15^{\circ} \mathrm{C}$ had a higher progressive motility score than semen held at 28 and $5 \sim 28^{\circ} \mathrm{C}(P$ $<0.01)$ but did not differ from each other $(P>0.05)$. We detected an effect of bull on total and progressive motility $(P<0.01)$, with bulls ranging from 48.5 to $79.7 \%$ and from 43.6 to $71.1 \%$ for total and progressive motility, respectively. We found no bull $\times$ day or bull $\times$ temperature interaction on total and progressive motility $(P>0.05)$. Semen held at a constant $28^{\circ} \mathrm{C}$ resulted in the lowest total and progressive motility scores for all days of storage $(P<0.01)$ and resulted in a large proportion of agglutinated sperm, the percentage of which increased dramatically with increased duration of storage (data not recorded). Semen maintained at $5^{\circ} \mathrm{C}$ and $5 \sim 15^{\circ} \mathrm{C}$, although not differing from each other in relation to total and progressive motility $(P>0.05)$, had greater total and progressive motility scores than semen at $5 \sim 28^{\circ} \mathrm{C}(P<0.01)$. Overall, semen held at a constant $28^{\circ} \mathrm{C}$ exhibited poor motility with low VCL and VAP, but surprisingly recorded high progressive motion values with the highest linearity, straightness, and wobble, and the lowest ALH values compared with storage temperatures of 5 or $15^{\circ} \mathrm{C}, 5 \sim 15^{\circ} \mathrm{C}$, and $5 \sim 28^{\circ} \mathrm{C}$ $(P<0.01$; Table 1$)$. Sperm stored at all other storage temperatures were exhibited slightly hypermotility, indicated by the high VCL and ALH values, and did not differ in motility kinematics between each other $(P>$ $0.05)$. Treatment had no effect on straight line velocity or on proximal and distal droplets $(P>0.05)$.

\section{Experiment 2: Effect of Storage Temperature on Field Fertility of Liquid Semen}

We detected a treatment $x$ day interaction as semen stored at a constant $5^{\circ} \mathrm{C}$ on d 1 and 2 of storage had a reduced NRR compared with all other treatments $(P<0.01$; Figure 2$)$; however, NRR did not differ be- 
Table 1. The overall effect of storage temperature on total and progressive motility and kinematic parameters as assessed using computerassisted sperm analysis in bovine semen stored at 5,15 , or $28^{\circ} \mathrm{C}$, fluctuating between 5 and $15^{\circ} \mathrm{C}$, or between 5 and $28^{\circ} \mathrm{C}$ (experiment 1 )

\begin{tabular}{|c|c|c|c|c|c|c|}
\hline \multirow[b]{2}{*}{ Parameter } & \multicolumn{5}{|c|}{ Storage temperature (mean \pm SEM) } & \multirow{2}{*}{ 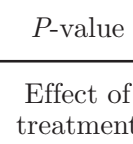 } \\
\hline & $5^{\circ} \mathrm{C}$ & $15^{\circ} \mathrm{C}$ & $28^{\circ} \mathrm{C}$ & $\begin{array}{c}\text { Fluctuating } \\
5 \text { to } 15^{\circ} \mathrm{C}\end{array}$ & $\begin{array}{c}\text { Fluctuating } \\
5 \text { to } 28^{\circ} \mathrm{C}\end{array}$ & \\
\hline Progressive motility (\%) & $57.0 \pm 2.59^{\mathrm{a}}$ & $66.9 \pm 1.68^{\mathrm{a}}$ & $46.9 \pm 2.57^{\mathrm{b}}$ & $58.2 \pm 2.66^{\mathrm{a}}$ & $50.4 \pm 3.59^{\mathrm{b}}$ & $<0.01$ \\
\hline $\mathrm{ALH}(\mu \mathrm{m})$ & $11.3 \pm 0.22^{\mathrm{a}}$ & $10.7 \pm 0.21^{\mathrm{a}}$ & $8.4 \pm 0.21^{\mathrm{b}}$ & $11.3 \pm 0.19^{\mathrm{a}}$ & $11.1 \pm 0.21^{\mathrm{a}}$ & $<0.01$ \\
\hline $\mathrm{BCF}(\mathrm{Hz})$ & $23.5 \pm 0.47^{\mathrm{a}}$ & $27.7 \pm 0.62^{\mathrm{b}}$ & $29.3 \pm 0.42^{\mathrm{b}}$ & $24.6 \pm 0.45^{\mathrm{a}}$ & $25.4 \pm 0.42^{\mathrm{a}}$ & $<0.01$ \\
\hline $\operatorname{VAP}(\mu \mathrm{m} / \mathrm{s})$ & $116.7 \pm 1.58^{\mathrm{a}}$ & $123.2 \pm 1.15^{\mathrm{a}}$ & $105.0 \pm 2.67^{\mathrm{b}}$ & $118.2 \pm 1.60^{\mathrm{a}}$ & $117.6 \pm 1.82^{\mathrm{a}}$ & $<0.01$ \\
\hline $\mathrm{VCL}(\mu \mathrm{m} / \mathrm{s})$ & $235.5 \pm 4.04^{\mathrm{a}}$ & $240.6 \pm 3.22^{\mathrm{a}}$ & $198.8 \pm 5.69^{\mathrm{b}}$ & $239.2 \pm 2.91^{\mathrm{a}}$ & $239.3 \pm 3.96^{\mathrm{a}}$ & $<0.01$ \\
\hline $\operatorname{VSL}(\mu \mathrm{m} / \mathrm{s})$ & $82.5 \pm 2.23$ & $91.9 \pm 1.85$ & $87.1 \pm 2.27$ & $84.7 \pm 2.75$ & $86.9 \pm 2.65$ & NS \\
\hline WOB $(\%)$ & $50.6 \pm 0.77^{\mathrm{a}}$ & $52.7 \pm 0.59^{\mathrm{a}}$ & $55.0 \pm 0.56^{\mathrm{b}}$ & $50.5 \pm 0.76^{\mathrm{a}}$ & $50.5 \pm 0.76^{\mathrm{a}}$ & $<0.01$ \\
\hline Proximal droplets (\%) & $3.9 \pm 2.31$ & $3.2 \pm 1.73$ & $4.2 \pm 2.45$ & $3.8 \pm 2.03$ & $3.9 \pm 2.19$ & NS \\
\hline Distal droplets (\%) & $4.4 \pm 0.25$ & $3.6 \pm 0.18$ & $3.7 \pm 0.22$ & $4.3 \pm 0.23$ & $4.2 \pm 0.24$ & NS \\
\hline
\end{tabular}

${ }^{\mathrm{a}-\mathrm{c}}$ Values with different superscripts differ significantly within row $(P<0.01)$.

$\mathrm{ALH}=$ amplitude of lateral head displacement, $\mathrm{BCF}=$ beat cross frequency, LIN = linearity, STR $=$ straightness, VAP $=$ average path velocity, $\mathrm{VCL}=$ curvilinear velocity, $\mathrm{VSL}=$ straight line velocity, $\mathrm{WOB}=$ wobble.
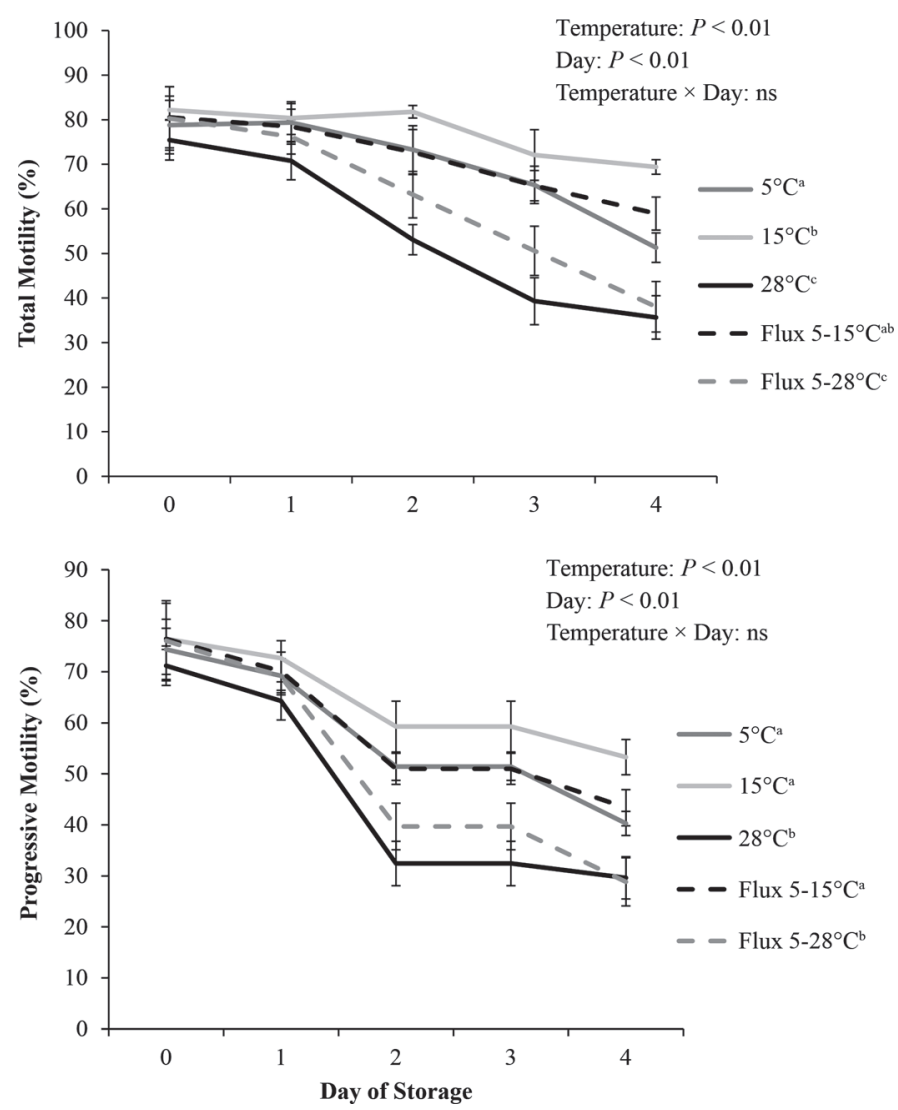

Figure 1. The effect of storage temperature on total motility (upper panel) and progressive motility (lower panel) of liquid bovine semen on d 0,1,2, 3 and 4 after collection (experiment 1) as assessed using computer-assisted sperm analysis. Vertical bars represent SEM. Temperatures with different letters $(\mathrm{a}-\mathrm{c})$ differ significantly $(P<$ $0.01)$; letters refer to overall effect of temperature on motility. tween frozen-thawed semen or any other temperature on $\mathrm{d} 1$ or $\mathrm{d} 2$ of storage $(P>0.05)$. Semen stored at a constant $5^{\circ} \mathrm{C}$ had a reduced $60-\mathrm{d}$ NRR compared with semen stored at a constant $15^{\circ} \mathrm{C}$, unregulated, or frozen-thawed semen $(74.4 \%)$. Overall, insemination with liquid semen on d 1 after collection resulted in similar NRR $(74.4 \%)$ to that of frozen-thawed semen $(74.4 \% ; P$ $>0.05)$; however, inseminations with liquid semen on $\mathrm{d}$ 2 of storage resulted in a lower NRR $(73.2 \%)$ compared with semen used on d $1(P<0.05)$ and with frozenthawed semen $(P<0.01)$. We detected an effect of bull on NRR $(P<0.01)$, with NRR for individual bulls varying from 69.9 to $78.7 \%$ (Table 2). There was a bull $\times$ treatment interaction as all bulls had a lower NRR for semen stored at $5^{\circ} \mathrm{C}$ compared with all other treatments $(P<0.01)$ with the exception of bulls $\mathrm{K}$ and $\mathrm{L}$ $(P>0.05)$. A bull $\times$ day interaction $(P<0.01)$ was observed, explained by bulls $\mathrm{F}$ and $\mathrm{H}$ having a higher NRR on d 1 than on d $2(P<0.05$; Table 2$)$. Bulls $\mathrm{C}$, $\mathrm{F}, \mathrm{H}$, and $\mathrm{K}$ had a higher NRR when frozen-thawed semen was used compared with liquid semen on $\mathrm{d} 2$ $(P<0.05)$ but did not differ from NRR achieved with liquid semen inseminated on $\mathrm{d} 1(P>0.05)$. Bulls $\mathrm{E}$ and $\mathrm{M}$ had a reduced NRR when frozen-thawed semen was used compared with liquid semen inseminated on d $2(P<0.05)$, whereas bull $\mathrm{N}$ had a reduced NRR in frozen-thawed semen compared with liquid semen on d 1 and d $2(P<0.01)$. Semen type (fresh vs. frozenthawed) had no effect on NRR; however, there was a bull $\times$ semen type interaction $(P<0.01)$. Bulls $\mathrm{A}, \mathrm{C}$, $\mathrm{F}, \mathrm{K}$, and $\mathrm{H}$ had a higher NRR when used as frozenthawed semen compared with liquid semen $(P<0.05)$, whereas bulls E, G, M, and N had a higher NRR when used as liquid semen compared with frozen-thawed 
semen $(P<0.01)$; however, there was no difference in NRR between the remaining bulls $(P>0.05)$. We found an effect of parity, cow fertility sub-index, and DIM on NRR $(P<0.01)$. Maiden heifers had a higher NRR $(87.2 \%)$ than primiparous and multiparous dairy cows $(73.6$ and $71.8 \%$, respectively; $P<0.01$ ). Cows with a fertility sub-index greater than $€ 70$ recorded a higher NRR than cows with a fertility sub-index of less than $€ 70$ ( 77.9 vs. $73.3 \%$, respectively; $P<0.01$ ). Nonreturn rate increased linearly with increasing DIM $(P$ $<0.01)$. As expected, NRR varied between individual herds and technicians $(P<0.01)$. There was no effect of cow breed and no breed, parity, cow fertility subindex, DIM, herd, or technician $\times$ storage temperature interaction $(P>0.05)$.

\section{DISCUSSION}

This study illustrates the importance of matching the storage conditions to the diluent used. We recently reported that INRA96, a milk-based diluent, could be used as an alternative to the industry standard Caprogen for the storage of liquid bovine semen, with the advantage of being ready to use off-the-shelf. Here, we took the approach of using split ejaculates and a combination of in vitro and in vivo assessments in a comprehensive attempt to identify the optimal semen storage temperature for liquid bovine semen stored in INRA96. The main findings of the study were (1) that semen stored in INRA96 at a constant $15^{\circ} \mathrm{C}$ resulted in greater sperm quality than semen stored at 5 or $28^{\circ} \mathrm{C}$ or fluctuating between 5 and $28^{\circ} \mathrm{C}$; and (2) that semen stored at a constant $15^{\circ} \mathrm{C}$ resulted in greater NRR on $\mathrm{d}$ 1 and 2 of storage than semen stored at $5^{\circ} \mathrm{C}$ but did not differ from that of liquid semen stored at unregulated temperature or frozen-thawed semen.

Motility assessment constitutes an integral part of semen quality control, with the use of CASA systems allowing an objective assessment of sperm motility kinematics (Verstegen et al., 2002). It is widely accepted

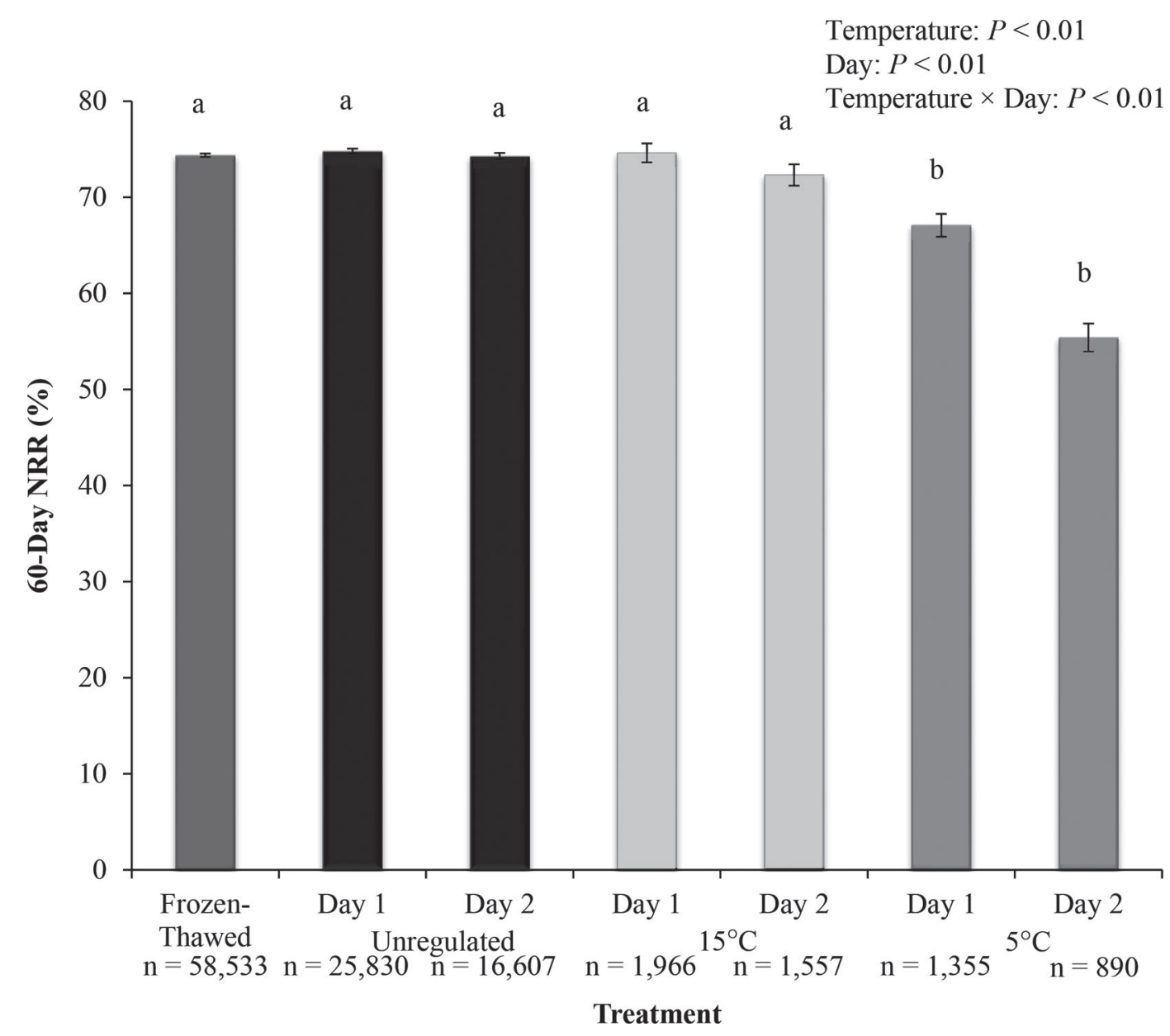

Figure 2. The effect of storage temperature and day of storage on 60-d nonreturn rate (NRR) in dairy cows and heifers (experiment 2). Vertical bars represent $95 \% \mathrm{CI} ; \mathrm{n}=$ number of inseminations. Values with different letters $(\mathrm{a}, \mathrm{b})$ differ significantly $(P<0.01)$. 
Table 2. The effect of liquid bovine semen inseminated on d 1 or 2 after collection and frozen-thawed semen on 60-d nonreturn rate in dairy cows and heifers (experiment 2)

\begin{tabular}{|c|c|c|c|c|}
\hline \multirow[b]{2}{*}{ Bull } & \multicolumn{3}{|c|}{ Nonreturn rate $[\%(\mathrm{n})]^{1}$} & \multirow[b]{2}{*}{$P$-value } \\
\hline & Liquid d 1 & Liquid d 2 & Frozen-thawed & \\
\hline A & $\begin{array}{c}69.9^{\mathrm{a}} \\
(1,165)\end{array}$ & $\begin{array}{l}72.2^{\mathrm{ab}} \\
(759)\end{array}$ & $\begin{array}{c}75.4^{\mathrm{b}} \\
(1.772)\end{array}$ & $<0.01$ \\
\hline B & $\begin{array}{r}77.6 \\
(1,243)\end{array}$ & $\begin{array}{r}75.0 \\
(1,166)\end{array}$ & $\begin{array}{c}73.9 \\
(1,983)\end{array}$ & NS \\
\hline $\mathrm{C}$ & $\begin{array}{c}72.5^{\mathrm{ab}} \\
(109)\end{array}$ & $\begin{array}{l}71.5^{\mathrm{b}} \\
(747)\end{array}$ & $\begin{array}{c}78.8^{\mathrm{a}} \\
(2,322)\end{array}$ & $<0.01$ \\
\hline D & $\begin{array}{c}69.7 \\
(1,718)\end{array}$ & $\begin{array}{c}71.0 \\
(1,135)\end{array}$ & $\begin{array}{c}69.1 \\
(1,151)\end{array}$ & NS \\
\hline $\mathrm{E}$ & $\begin{array}{c}75.8^{\mathrm{ab}} \\
(1,537)\end{array}$ & $\begin{array}{c}77.2^{\mathrm{b}} \\
(890)\end{array}$ & $\begin{array}{c}73.1^{\mathrm{a}} \\
(6,768)\end{array}$ & $<0.01$ \\
\hline $\mathrm{F}$ & $\begin{array}{c}78.2^{\mathrm{a}} \\
(734)\end{array}$ & $\begin{array}{l}72.5^{\mathrm{b}} \\
(541)\end{array}$ & $\begin{array}{c}79.5^{\mathrm{a}} \\
(4,612)\end{array}$ & $<0.01$ \\
\hline G & $\begin{array}{c}74.3^{\mathrm{a}} \\
(2,111)\end{array}$ & $\begin{array}{c}71.1^{\mathrm{ab}} \\
(1,117)\end{array}$ & $\begin{array}{c}69.8^{\mathrm{b}} \\
(4.689)\end{array}$ & $<0.01$ \\
\hline $\mathrm{H}$ & $\begin{array}{c}78.7^{\mathrm{a}} \\
(4,198)\end{array}$ & $\begin{array}{c}75.5^{\mathrm{b}} \\
(2,041)\end{array}$ & $\begin{array}{c}79.5^{\mathrm{a}} \\
(5,886)\end{array}$ & $<0.01$ \\
\hline I & $\begin{array}{c}76.6 \\
(1,710)\end{array}$ & $\begin{array}{c}73.6 \\
(1,011)\end{array}$ & $\begin{array}{c}74.0 \\
(7,846)\end{array}$ & NS \\
\hline $\mathrm{J}$ & $\begin{array}{c}73.1 \\
(2,498)\end{array}$ & $\begin{array}{c}70.9 \\
(2,171)\end{array}$ & $\begin{array}{c}70.8 \\
(1,457)\end{array}$ & NS \\
\hline K & $\begin{array}{c}75.4^{\mathrm{ab}} \\
(1,448)\end{array}$ & $\begin{array}{l}71.9^{\mathrm{b}} \\
(950)\end{array}$ & $\begin{array}{c}77.6^{\mathrm{a}} \\
(1,763)\end{array}$ & $<0.01$ \\
\hline $\mathrm{L}$ & $\begin{array}{c}71.4 \\
(1,224)\end{array}$ & $\begin{array}{c}75.3 \\
(790)\end{array}$ & $\begin{array}{c}74.9 \\
(2,311)\end{array}$ & NS \\
\hline M & $\begin{array}{c}73.2^{\mathrm{ab}} \\
(930)\end{array}$ & $\begin{array}{l}75.0^{\mathrm{b}} \\
(721)\end{array}$ & $\begin{array}{c}70.3^{\mathrm{a}} \\
(2,546)\end{array}$ & $<0.05$ \\
\hline $\mathrm{N}$ & $\begin{array}{c}73.2^{\mathrm{a}} \\
(4,087)\end{array}$ & $\begin{array}{c}72.6^{\mathrm{a}} \\
(2,148)\end{array}$ & $\begin{array}{c}69.7^{\mathrm{b}} \\
(4,593)\end{array}$ & $<0.01$ \\
\hline $\mathrm{O}$ & $\begin{array}{c}76.7 \\
(1,111)\end{array}$ & $\begin{array}{c}72.8 \\
(894)\end{array}$ & $\begin{array}{c}74.9 \\
(3,267)\end{array}$ & NS \\
\hline $\mathrm{P}$ & $\begin{array}{r}73.7 \\
(3,328)\end{array}$ & $\begin{array}{c}74.1 \\
(1,973)\end{array}$ & $\begin{array}{c}74.8 \\
(5,567)\end{array}$ & NS \\
\hline Overall & $\begin{array}{c}74.4^{\mathrm{a}} \\
(29,151)\end{array}$ & $\begin{array}{c}73.2^{\mathrm{b}} \\
(19,054)\end{array}$ & $\begin{array}{c}74.4^{\mathrm{a}} \\
(58,533)\end{array}$ & $<0.01$ \\
\hline
\end{tabular}

${ }^{\mathrm{a}, \mathrm{b}}$ Values in the same row with different superscripts differ significantly $(P<0.01)$.

${ }^{1} \mathrm{n}=$ total number of inseminations per treatment per day.

that regardless of storage temperature, sperm motility and fertility decline over an extended period, with bull sperm reported to exhibit a gradual decline in motility for up to $4 \mathrm{wk}$ while there is a sharp decline in NRR after $5 \mathrm{~d}$ of semen storage (Vishwanath and Shannon, 2000). In agreement, the results of the current study demonstrate that semen quality measured in terms of total and progressive motility declined with increased duration of storage, regardless of storage temperature. Several studies have reported a correlation between sperm motility kinematics and fertility (Kathiravan et al., 2008; Oliveira et al., 2013; Nagy et al., 2015); however, Amann and Waberski (2014) and Amann et al. (2017) suggest that sperm kinematic characteristics are not an accurate predictor of fertilizing potential but instead could be used to provide important information relating to the quality assurance of semen. Surprisingly, in the current study, semen held at $28^{\circ} \mathrm{C}$ recorded higher progressive motion values than semen any at other storage temperature; however, storing semen at extreme high temperatures of $28^{\circ} \mathrm{C}$ was detrimental to sperm as they exhibited reduced overall motility and velocity values. All other storage temperatures recorded similar kinematic parameters. The results of this study highlight that sperm are quite tolerant to a variation in temperature in terms of sperm quality, retaining acceptable in vitro standards between storage temperatures of 5 and $15^{\circ} \mathrm{C}$; however, storing semen at a constant $15^{\circ} \mathrm{C}$ resulted in the best semen quality throughout the duration of storage. Therefore, we could postulate that the components of INRA96 interact similarly with semen at different storage temperature conditions. The results of this study support the findings of Murphy et al. (2015), who previously reported that semen stored in Caprogen at $15^{\circ} \mathrm{C}$ had greater motility than semen stored at 5,22 , or $32^{\circ} \mathrm{C}$, or 
at fluctuating temperatures between 5 and $15^{\circ} \mathrm{C}, 5$ and $22^{\circ} \mathrm{C}$, or 5 and $32^{\circ} \mathrm{C}$.

Although milk-based extenders are more widely used at temperatures between 4 and $8^{\circ} \mathrm{C}$, INRA96 has also been shown to be beneficial in the preservation of equine sperm stored at $15^{\circ} \mathrm{C}$. The results of the current study demonstrate that bovine semen diluted in INRA96 resulted in greater NRR on $\mathrm{d} 1$ and $\mathrm{d} 2$ of storage when semen was stored at a constant $15^{\circ} \mathrm{C}$ or unregulated temperature compared with storage at a constant $5^{\circ} \mathrm{C}$. Furthermore, INRA96 diluent was effective in protecting sperm from temperature fluctuations under unregulated field conditions and supports the in vitro findings of Murphy et al. (2017). The current results are similar to the in vitro findings of Batellier et al. (1997) and the fertility findings of Cuervo-Arango et al. (2014) and Batellier et al. (2001), who reported better in vitro survival and fertility of equine sperm stored in INRA96 at $15^{\circ} \mathrm{C}$ compared with $4^{\circ} \mathrm{C}$, respectively. Surprisingly, in the current study, semen stored at a constant $5^{\circ} \mathrm{C}$ had a reduced NRR on both d 1 and d 2 of storage compared with semen stored at unregulated temperature and frozen-thawed semen. All bulls except 2 (bulls $\mathrm{K}$ and $\mathrm{L}$ ) performed relatively poorly when semen was stored at a constant $5{ }^{\circ} \mathrm{C}$ compared with any other storage conditions. A possible explanation for the poor fertility performance of liquid semen stored at $5^{\circ} \mathrm{C}$ may be the inability of sperm from these bulls to adapt to the lower storage temperature, increasing the incidence of cold shock injuries, which could result in a decline in sperm membrane integrity due to a loss of phospholipids, causing membrane impairment and a reduction in fertility (Batellier et al., 2001). However, no evidence of cold shock injuries was observed when assessing these samples in vitro. In addition, the in vitro results of the current study highlight that storage conditions fluctuating between 5 and $28^{\circ} \mathrm{C}$ resulted in a significant loss of sperm motility, suggesting that exposure to such day- to nighttime temperature fluctuations typically observed in the field could result in a decline in membrane integrity as a consequence of membrane changes consistent with the lipid phase transition (Drobnis et al., 1993). However, the fertility results of the current study do not support this because storage at a constant $5{ }^{\circ} \mathrm{C}$ was more detrimental to NRR than unregulated temperature storage conditions.

In the current study, there was no effect of semen type (liquid vs. frozen) on nonreturn rates, and semen type did not nullify the effects of cow characteristics, such as DIM, parity, cow fertility subindex, and so on, on fertility. The use of liquid semen has many advantages in that it promotes and maximizes the utilization of genetically superior sires, because of the reduced sperm concentration per straw, and therefore generates a greater number of straws per ejaculate than frozen-thawed semen. This facilitates the acceleration of genetic gain through more intensive sire utilization and provides a distinct advantage to AI centers, particularly in relation to young genomically selected superior sires, as the advent of genomics has placed additional pressure on AI centers to better utilize this valuable semen. Although young sires are now in high demand, they produce lower volumes of semen compared with their mature counterparts (Brito et al., 2002 ); thus, the use of liquid semen provides a significant advantage to AI centers as semen production can be maximized. However, it is widely acknowledged that fertility from individual bulls varies by $\sim 20$ to $25 \%$, even when semen meets minimum routine quality control standards (Kastelic and Thundathil, 2008; Holden et al., 2017). The results of the current study highlight that bull variation exists between semen type, with some bulls having a higher NRR when used for liquid versus frozen-thawed semen or vice versa. Anzar et al. (2002) reported that the number of apoptotic cells in liquid semen differs between bulls, whereas Murphy et al. (2015) and Murphy et al. (2017) reported that sperm of some bulls is more susceptible to aging effects when stored in liquid semen. The production of reactive oxygen species, which ultimately leads to an apoptotic cascade in which sperm lose their motility, DNA integrity, and vitality (Aitken et al., 2012), may be linked to the aging effect, leading to a reduction in fertility. The results of the current study agree with this sperm aging effect because although only 3 bulls had a significant decline in NRR on d 2 of storage of liquid semen, $62.5 \%$ of bulls had a numerical decline in NRR on d 2 compared with d 1 of storage, indicating that some bulls are better able to maintain semen longevity in terms of prolonged storage days without a decrease in fertility. Furthermore, although it is widely accepted that cow characteristics such as parity, fertility subindex, and DIM play a role in fertility (Murphy et al., $2015,2017)$, storage temperature does not nullify the effects of these because no interaction between storage temperature and cow characteristics was observed. Consistent with previous reports (Pursley et al., 1997; Gabriel et al., 2011), maiden heifers had a significantly higher NRR compared with primiparous and multiparous dairy cows with an increase in NRR of $\sim 14$ and $15 \%$, respectively.

\section{CONCLUSIONS}

Bovine semen held at a constant $15^{\circ} \mathrm{C}$ had the highest total and progressive motility score over the duration of 
storage; however, our results also highlight that sperm are quite tolerant to variation in storage temperature and can retain acceptable motility when stored between 5 and $15^{\circ} \mathrm{C}$. Semen held at a constant $15^{\circ} \mathrm{C}$ resulted in similar NRR to semen stored in unregulated storage conditions but NRR was significantly reduced at storage of $5^{\circ} \mathrm{C}$. In climatic conditions where daytime to nighttime temperature fluctuations are large, a stricter temperature regulation regimen should be put in place for liquid semen, with a storage temperature of $15^{\circ} \mathrm{C}$ being most desirable. In circumstances or field conditions where maintaining a constant temperature is not possible, unregulated storage conditions result in acceptable fertility; however; provisions should be put in place to avoid exposure of liquid semen to extreme temperatures.

\section{ACKNOWLEDGMENTS}

This work was supported by the Irish Research Council, Department of Agriculture, Food and the Marine and Teagasc under grant number EBPPG/2014/60. The authors gratefully acknowledge Munster Cattle Breeding Group (Ballyvorshine, Mallow, Co. Cork, Ireland) and Progressive Genetics (Enfield, Co. Meath, Ireland) for the distribution of semen straws.

\section{REFERENCES}

Aitken, R. J., K. T. Jones, and S. A. Robertson. 2012. Reactive oxygen species and sperm function-In sickness and in health. J. Androl. 33:1096-1106.

Amann, R. P., R. G. Saacke, G. F. Barbato, and D. Waberski. 2017. Measuring male-to-male differences in fertility or effects of semen treatments. Annu. Rev. Anim. Biosci. 6:255-286.

Amann, R. P., and D. Waberski. 2014. Computer-assisted sperm analysis (CASA): Capabilities and potential developments. Theriogenology 81:5-17.e1.

Anzar, M., L. He, M. M. Buhr, T. G. Kroetsch, and K. P. Pauls. 2002. Sperm apoptosis in fresh and cryopreserved bull semen detected by flow cytometry and its relationship with fertility. Biol. Reprod. 66:354-360.

Ball, B. A., V. Medina, C. Gravance, and J. Baumber. 2001. Effect of antioxidants on preservation of motility, viability and acrosomal integrity of equine spermatozoa during storage at $5 \mathrm{C}$. Theriogenology 56:577-589.

Batellier, F., M. Magistrini, J. Fauquant, and E. Palmer. 1997. Effect of milk fractions on survival of equine spermatozoa. Theriogenology 48:391-410.

Batellier, F., M. Vidament, J. Fauquant, G. Duchamp, G. Arnaud, J. Yvon, and M. Magistrini. 2001. Advances in cooled semen technology. Anim. Reprod. Sci. 68:181-190.

Berry, D., L. Shalloo, A. Cromie, V. Olori, and P. Amer. 2005. Economic breeding index for dairy cattle in Ireland. Irish Cattle Breeding Federation, Bandon, Cork, Ireland.

Black, N. 2006. Artificial insemination of cattle. Anim. Reprod. Sci. 10:6-15.

Brito, L. F., A. Silva, L. Rodrigues. F. Vieira, L. Deragon, and J. Kastelic. 2002. Effect of age and genetic group on characteristics of the scrotum, testes and testicular vascular cones, and on sperm production and semen quality in AI bulls in Brazil. Theriogenology 58:1175-1186.

Cuervo-Arango, J., K. Nivola, and T. Katila. 2014. The effect of storage temperature of equine transported semen on pregnancy rates and spermatozoal quality. J. Equine Vet. Sci. 34:91-93.

Drobnis, E. Z., L. M. Crowe, T. Berger, T. J. Anchordoguy, J. W. Overstreet, and J. H. Crowe. 1993. Cold shock damage is due to lipid phase transitions in cell membranes: A demonstration using sperm as a model. J. Exp. Zool. 265:432-437.

Foote, R. 1964. Influence of $\mathrm{pH}$ on survival and fertility of bull sperm. J. Dairy Sci. 47:807-811.

Gabriel, H. G., S. Wallenhorst, E. Dietrich, and W. Holtz. 2011. The effect of prostaglandin F2 $\alpha$ administration at the time of insemination on the pregnancy rate of dairy cows. Anim. Reprod. Sci. 123:1-4.

Gil, J., S. Fierro, O. Bentancur, and J. Olivera-Muzante. 2011. Chilled storage of ram semen improves with the addition of egg yolk and glycerol to milk-based extenders. Reprod. Domest. Anim. 46:503507.

Holden, S. A., B. Fernandez-Fuertes, C. Murphy, H. Whelan, A. O'Gorman, L. Brennan, S. Butler, P. Lonergan, and S. Fair. 2017. Relationship between in vitro sperm functional assessments, seminal plasma composition, and field fertility after AI with either non-sorted or sex-sorted bull semen. Theriogenology 87:221-228.

Irish Cattle Breeding Federation (ICBF). 2017. Economic Breeding Index (EBI). Accessed May. 16, 2017. https://www.icbf.com/wp/ $? \mathrm{p}=5852$.

Irish Statue Book. 2004. European Communities (Trade in Bovine Breeding Animals, Their Semen, Ova and Embryos) (Amendment) Regulations. Accessed Sep. 25, 2017. http://www.irishstatutebook .ie/eli/2004/si/499/made/en/print.

Kastelic, J. P., and J. Thundathil. 2008. Breeding soundness evaluation and semen analysis for predicting bull fertility. Reprod. Domest. Anim. 43:368-373.

Kathiravan, P., J. Kalatharan, M. J. Edwin, and C. Veerapandian. 2008. Computer automated motion analysis of crossbred bull spermatozoa and its relationship with in vitro fertility in zona-free hamster oocytes. Anim. Reprod. Sci. 104:9-17.

Met Éireann. 2017. Daily temperatures. Accessed Nov. 3, 2017. http:// www.met.ie/climate/daily-data.asp.

Mortimer, S. T. 2000. CASA—Practical aspects. J. Androl. 21:515524.

Murphy, C., A. Fahey, A. Shafat, and S. Fair. 2013. Reducing sperm concentration is critical to limiting the oxidative stress challenge in liquid bull semen. J. Dairy Sci. 96:4447-4454.

Murphy, C., S. A. Holden, E. M. Murphy, A. R. Cromie, P. Lonergan, and S. Fair. 2015. The impact of storage temperature and sperm number on the fertility of liquid-stored bull semen. Reprod. Fertil. Dev. 28:1349-1359.

Murphy, E. M., C. Murphy, C. O'Meara, G. Dunne, B. Eivers, P. Lonergan, and S. Fair. 2017. A comparison of semen diluents on the in vitro and in vivo fertility of liquid bull semen. J. Dairy Sci. 100:1541-1554.

Nagy, Á., T. Polichronopoulos, A. Gáspárdy, L. Solti, and S. Cseh. 2015. Correlation between bull fertility and sperm cell velocity parameters generated by computer-assisted semen analysis. Acta Vet. Hung. 63:370-381.

O'Hara, L., J. Hanrahan, L. Richardson, A. Donovan, S. Fair, A. Evans, and P. Lonergan. 2010. Effect of storage duration, storage temperature, and diluent on the viability and fertility of fresh ram sperm. Theriogenology 73:541-549.

Oliveira, L. Z., R. P. de Arruda, A. F. C. de Andrade, E. C. C. Celeghini, P. D. Reeb, J. P. N. Martins, R. M. dos Santos, M. E. Beletti, R. F. G. Peres, and F. M. Monteiro. 2013. Assessment of in vitro sperm characteristics and their importance in the prediction of conception rate in a bovine timed-AI program. Anim. Reprod. Sci. 137:145-155.

Pino, J. A., N. Osses, D. Oyarzun, J. G. Farías, R. D. Moreno, and J. G. Reyes. 2013. Differential effects of temperature on reactive oxy- 
gen/nitrogen species production in rat pachytene spermatocytes and round spermatids. Reproduction 145:203-212.

Pursley, J. R., M. Wiltbank, J. Stevenson, J. Ottobre, H. Garverick, and L. Anderson. 1997. Pregnancy rates per artificial insemination for cows and heifers inseminated at a synchronized ovulation or synchronized estrus1. J. Dairy Sci. 80:295-300.

Salisbury, G. W., and N. L. Vandemark. 1961. Physiology of Reproduction and Artificial Insemination of Cattle. Agricultural Science series. W. H. Freeman and Co., San Francisco, CA.

Shannon, P. 1965. Contribution of seminal plasma, sperm numbers, and gas phase to dilution effects of bovine spermatozoa. J. Dairy Sci. 48:1357-1361.

Shannon, P., and B. Curson. 1984. Effect of storage temperature on the viability and fertility of bovine sperm diluted and stored in Caprogen. N. Z. J. Agric. Res. 27:173-177.
Shannon, P., B. Curson, and A. Rhodes. 1984. Relationship between total spermatozoa per insemination and fertility of bovine semen stored in Caprogen at ambient temperature. N. Z. J. Agric. Res. $27: 35-41$.

Verberckmoes, S., A. Van Soom, J. Dewulf, and A. de Kruif. 2005. Comparison of three diluents for the storage of fresh bovine semen. Theriogenology 63:912-922.

Verstegen, J., M. Iguer-Ouada, and K. Onclin. 2002. Computer assisted semen analyzers in andrology research and veterinary practice. Theriogenology 57:149-179.

Vishwanath, R. C. Pitt, and P. Shannon. 1996. Sperm numbers, semen age and fertility in fresh and frozen bovine semen. N. Z. Soc. Anim. Prod. 56:31-33.

Vishwanath, R., and P. Shannon. 2000. Storage of bovine semen in liquid and frozen state. Anim. Reprod. Sci. 62:23-53. 